
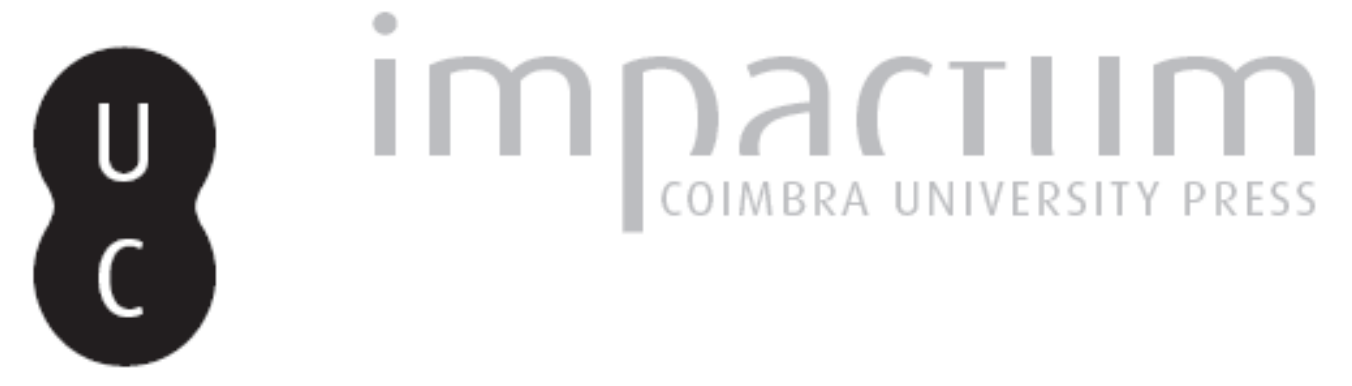

\title{
António Sérgio: claridade e sombras
}

\section{Autor(es): Marnoto, Isabel}

Publicado por: Imprensa da Universidade de Coimbra

URL persistente:

URl:http://hdl.handle.net/10316.2/45042

DOI:

DOI:https://doi.org/10.14195/2183-8925_5-1_3

Accessed : $\quad$ 26-Apr-2023 10:17:48

A navegação consulta e descarregamento dos títulos inseridos nas Bibliotecas Digitais UC Digitalis, UC Pombalina e UC Impactum, pressupõem a aceitação plena e sem reservas dos Termos e Condições de Uso destas Bibliotecas Digitais, disponíveis em https://digitalis.uc.pt/pt-pt/termos.

Conforme exposto nos referidos Termos e Condições de Uso, o descarregamento de títulos de acesso restrito requer uma licença válida de autorização devendo o utilizador aceder ao(s) documento(s) a partir de um endereço de IP da instituição detentora da supramencionada licença.

Ao utilizador é apenas permitido o descarregamento para uso pessoal, pelo que o emprego do(s) título(s) descarregado(s) para outro fim, designadamente comercial, carece de autorização do respetivo autor ou editor da obra.

Na medida em que todas as obras da UC Digitalis se encontram protegidas pelo Código do Direito de Autor e Direitos Conexos e demais legislação aplicável, toda a cópia, parcial ou total, deste documento, nos casos em que é legalmente admitida, deverá conter ou fazer-se acompanhar por este aviso.

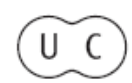




\section{REVISTA DE HISTÓRIA DAS IDEIAS 5}

\section{António Sérgio}

*

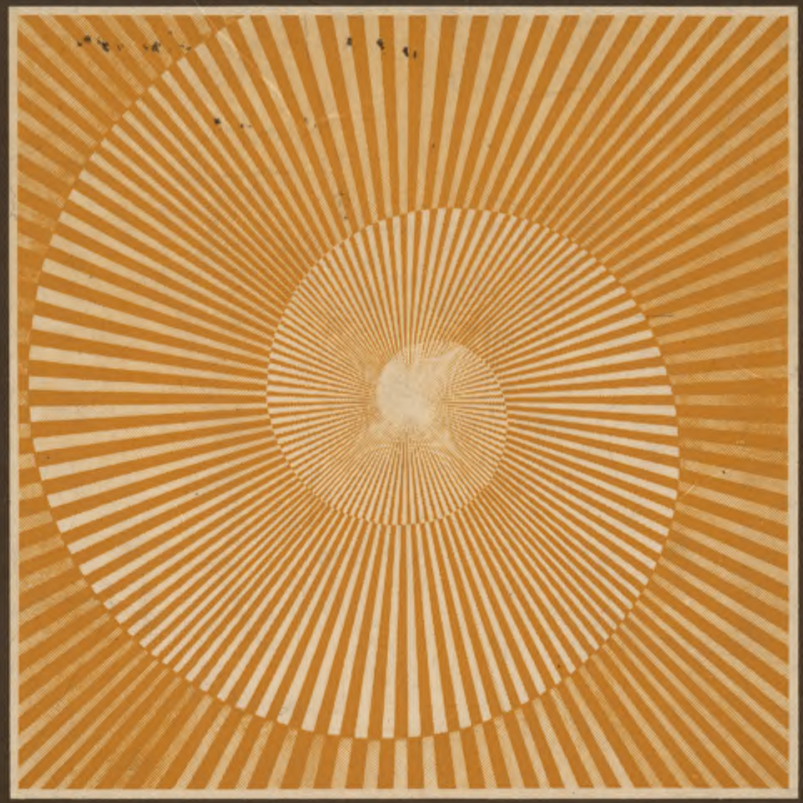

INSTITUTO DE HISTÓRIA E TEORIA DAS IDEIAS FACULDADE DE LETRAS 


\title{
ANTONIO SÉRGIO: CLARIDADES E SOMBRAS
}

\author{
Não creio na ordem que só vem da \\ espada. Tenho procedido na minha vida \\ como se as ideias mais claras do meu \\ espírito representassem a ordem essencial \\ do mundo. Busco a harmonia dentro de \\ $\operatorname{mim} .$.
}

António Sérgio, Antigona

Sérgio admirado e revisitado por alguns, agrupo fiel e constante que não poupa elogios nem esquece q «moscardo» que o ensaísta ilustre representou para as consciências do seu tempo.

Sérgio esquecido por muitos, não aprendido nem ensinado, muito menos discutido - e, assim, a cultura de um povo a medir-se, também, pela memória fraca e o interesse gasto.

Sérgio, de repente, na moda polémica - «abaixo o mito». Com desenvoltura exagerada, leviana muitas vezes, alguns destroem num segundo altos projectos de uma vida de dedicação à cultura. Com leituras superficiais (ou nulas) da sua obra, ao correr dos olhos sobre qualquer Antologia - e é o quanto baste para a demolição.

Mas também Sérgio, valha a verdade, objecto de crítica séria, fundamentada.

E de repente nos achamos: fora de moda se elogiosos, injustos e míopes, se críticos apressados, só para acompanhar a nova vaga?

Em 1983, que Sérgio? Que frescura possível no elogio, que calor na adesão, que circunstâncias a permitirem, hoje,

\footnotetext{
* Professora do Ensino Secundário.
} 


\section{Antonio Sérgio}

aceitarmos princípios nascidos em outras circunstâncias - outros tempos, outros modos...

Balanço feito, segue-se o texto, que não é fruto de adesão ligeira a certas modas, como também não é inócua manifestação de panegirista acrítico. Não será também a visão inovadora, o ponto de vista que faltava, a síntese agudíssima, aquela leitura que nunca antes se fizera. $\mathrm{O}$ trabalho que segue refere um Sérgio de espírito aventuroso - «mete-te à vaga corajosamente»- que acima de tudo trabalha para a emancipação do homem no pensamento, como na acção. Chamemos-lhe o domínio das claridades. Mas este trabalho refere também um Sérgio limitado na sua visão do mundo e do homem por um nacionalismo que, teimosamente, não quer deixar espaço de manobra para nenhuma outra forma de entender esse mesmo mundo. Um Sérgio para quem só o racional, o lógico, o conceptual, têm direito a ser e a se manifestar, na certeza de que só o intelecto dá sentido às coisas. Chamemos-lhe o domínio das sombras 0 ).

\section{DEMOCRACIA E RAZÃO}

Comecemos pelas claridades. Logo encontramos, porque se nos impõem, estas duas noções dependentes uma da outra: democracia e razão. Serão elas um núcleo donde partem todos os caminhos que Sérgio percorreu, um farol que ilumina percursos labirínticos - porque viver é sempre lutar, procurar, escolher - , mas também a possibilidade de se chegar, um dia, a porto seguro. Democracia e razão, afinal consciência humana: $\left(^{2}\right)$ em Sérgio, ponto de partida e ponto de chegada, teóricos, programáticos. $\mathrm{Na}$ prática, era a ditadura, reino cadaveroso de espectros, - um viajar em círculo, portanto: a razão encontra-se no princípio (é a possibilidade de) e encontra-se no fim (os resultados, teóricos ou práticos, serão sempre uma consequência lógica de premissas conscientes, racionais). Da razão se parte, à razão se chega, a luz permanece e o círculo fecha-se. O racionalismo, «essa maneira de ser com que nasci»».

A democracia não se separa, assim, dos ditames da consciência; por isso Sérgio diz: "a democracia não é uma escola política, no género das escolas literárias. É um imperativo de consciência...»; e também: «a democracia é o sistema em que

\footnotetext{
O Sombras que aqui não figuram na acepção que Raul Proença utilizou para criticar o primeiro tomo dos Ensaios.

C) Consciência tomada no sentido epistemológico, como um foco de actividades e com carácter unificado e unificante.
} 
se deseja para o cidadão o máximo de consciência»; ou ainda: «o ideal democrático é eterno porque deriva da própria estrutura da consciência humana» ${ }^{3}$ ).

Olhando Sérgio agora, a esta distância, passados que são catorze anos da sua morte, cem anos do seu nascimento, e procurando distinguir, no conjunto da sua acção e pensamento, os contornos mais nítidos, serão estas duas noções que sobressaem, caracterizam uma obra e condicionam todos os caminhos por ele percorridos - do hábil exercício polémico, a uma acção concreta visando sempre o bem comum. Viver e «trabalhar pela unidade, pelo entendimento recíproco, pela existência de relações de convivência amável entre os homens políticos de orientações discordes. Incorrigivelmente «ingénuo», fraterno, cordial» $\left({ }^{4}\right)$. Entre os outros, para os outros, para um destino melhor do semelhante, na certeza de que é entre os homens, em sociedade, que o eu se desenvolve. Fala então em Cristo e em Sócrates como mestres de democracia; tal como Sócrates, também Sérgio está presente na Cidade, a força da sua consciência opondo-se à força do Estado, o espírito criador em busca de novas formas de vida social. E fala, a propósito, do respeito pela dignidade da pessoa humana que será sempre considerada como um fim e nunca como um meio.

Atraído Sérgio pelo pensamento grego, Platão será, para o ensaísta, como veremos, o Mestre incontestado de um racionalismo que se quer purifícado de todo o contacto com o sensível. E Sócrates, mestre do mestre, estará presente também, como é natural, tratando-se de um filósofo que a si mesmo se designa de «moscardo»: na acepção que Platão lhe deu, o «moscardo» possibilitará que uma democracia se cimente na base de uma razão que é esforço de compreensão das verdades mais altas (do inteligível). Tal como para António Sérgio. Afinal Sérgio também poderia ter dito, como Platão diz que Sócrates disse: «eu sou o moscardo que dia após dia não cessa de vos despertar, de vos aconselhar, de repreender cada um de vós...». Porque ambos, Sérgio e Sócrates, tiveram o gosto apaixonado do diálogo com toda a gente. E mantiveram ambos, também, uma luta acesa contra o pseudo-saber dos sofistas, contra a aparência da sabedoria que se toma como verdadeira sabedoria, contra a frivolidade intelectual: «que o que importa não é a sabença, mas o contributo da busca para a libertação do espírito» $\left({ }^{5}\right)$.

$\left({ }^{8}\right)$ Ensaios, VII, Lisboa, Sá da Costa, 1974, pp. 169-179.

C) Alocução aos socialistas no Banquete do Primeiro de Maio de 1947, Lisboa, Inquérito, p. 25.

(5) Ensaios, III. 
Foram assim, Sérgio e Sócrates, gente incómoda para os homens do seu tempo; porque críticos, porque democratas (cada um, naturalmente, a seu tempo e a seu modo). Ambos querendo «substituir progressivamente a autoridade externa.... pela autoridade interna em cada um de nós»: $\left(^{6}\right)$ um «conhece-te a ti próprio» que é risco assumido de análise aprofundada de si mesmo que não servirá, nem em Sérgio nem em Sócrates, para se firmar na singularidade dos temperamentos, nem para confirmar as afirmações cépticas dos sofistas, mas para procurar, através da Razão, o homem essencial - o que de comum e universal há em todos os homens. Ou seja: um humanismo em ambos que vise o universalismo. A distância de 2500 anos um do outro, estes dois homens falam, de certo modo, uma linguagem comum, linguagem simples, oposta à argumentação dos sofistas. Ambos põem em evidência a importância da virtude: porque a democracia será, para António Sérgio, uma atitude moral, antes de ser regime político. Ë preciso «procurar a virtude em todos os actos». Só pratica o Mal quem ignora o que é o Bem, já o dissera Marco Aurélio, disse-o Sócrates e, cheio de entusiasmo e (a seu modo) de paixão, — di-lo-á também António Sérgio. Em Sócrates, a procura e a determinação do Bem terá mais um sentido de ordem prática do que propriamente um interesse especulativo-interessaria mais a Sócrates a conduta recta do que a formulação abstracta de conceitos (embora Aristoteles, por exemplo, não partilhe esta opinião que é aceite por muitos autores). E em Sérgio, como veremos, a importância da acção dará ao seu humanismo uma feição esnecial.

Portanto, para os dois pensadores, se toma necessário ter conhecimentos claros para que se atinja a conduta recta; estabelecida que fica, deste modo, a relação entre o saber e o ser: virtude é conhecimento, é o que torna o homem capaz de viver em harmonia, de ser feliz, e uma arte que tende para o Bem e portanto forçoso se toma que esta finalidade seja conheçida.

E-se democrata, então, por imperativo da consciência, não há separação entre o homem moral e o homem político- «a maneira de preparar um viver democrático não é directamente pela política, mas sim indirectamente pela ordenação do espírito» $\left({ }^{7}\right)$. E ao mesmo tempo desenvolve-se uma capacidade racional quando se vive em democracia, porque essa capacidade será tanto mais desenvolvida quanto mais

C) Idem, VII, p. 238.

C) Idem, 


\section{Claridades e Sombras}

liberta, quanto mais capaz de germinar, florir, frutificar. 0 pensamento não basta, é necessária a acção. Afinal «o sentimento de felicidade, para um ser espiritual, se reduz a um sentimento de liberdade».

\section{Democracia é demopedia}

A liberdade é um dos tópicos mais importantes do pensamento de Sérgio. Ela está subjacente em todas as suas propostas e, num tempo de opressão, no país ou no exílio, ela é sempre aquela condição sem a qual nenhum projecto seu (pedagógico, político, histórico, filosófico) poderá vingar. Toda a sua obra «respira» e vive dessa liberdade (veremos adiante se algumas contradições do pensamento sergiano de certa forma a não limitarão).

E um facto que não poderá haver democracia se o povo estiver subjugado, se for ignorante, se aceitar passivamente tanto o que o promove como o que o rebaixa. Numa população perfeitamente abúlica e acrítica, que democracia possível? E como da necessidade de democracia se parte e se parte também, como vimos, da necessidade de uma consciência clara, uma e outra esclarecendo-se mutuamente, um primeiro passo se impõe e Sérgio deu-o, avançadas tantas vezes quixotescas se atendermos ao bolor e bafio de uma sociedade que, em Portugal, pelos anos 30, 40, 50, fazia por conservar-se resguardada das lufadas de ar fresco que só o verdadeiro espírito crítico, parente tão próximo da emancipação e da liberdade, proporciona. O primeiro passo para a realização plena da democracia será então a emancipação dos indivíduos, a educação do povo. Sabemos que Sergio, na linha de Proudhon, dirá Democracia é demopedia, na base do autodomínio, da objectividade, da ordenação do espírito, contra o «nosso eterno dogmatismo, a nossa estreitez de sectários, a falta de empenho em buscar conciliação de pareceres, plataformas de entendimento, laços de colaboração prestadia» $\left({ }^{8}\right)$.

Vamos percebendo a teia de relações, tão cara a Sérgio: Racionalismo, Emancipação, Democracia - conceitos que se vão entretecendo e parece evidente que se encontram no domínio das claridades: o que Sérgio diz, a este propósito, cabe em todos os tempos, sempre que os homens lutaram por princípios de igualdade e de justiça social. A emancipação do homem será um dos focos mais intensos das propostas de Sérgio e, por mais que mudem os tempos e os ventos, a luz

$\left.{ }^{8}\right)$ Democracia, 1. ${ }^{\text {a }}$ ed., Lisboa, Sá da Costa, 1974, p. 204. 


\section{Antonio Sérgio}

dessa verdade permanece; só pelo fervor combativo que ele pôs na defesa dessa liberdade para todos os homens (conquista que terá de ser feita por todos os homens, no íntimo de cada um, mas também no exterior, como cidadãos) ele seria digno de figurar entre os grandes vultos do pensamento e da acção.

Emancipar é, portanto, libertar, libertar-se cada um dos grilhões que impedem se olhe a luz autêntica, o sol, as coisas mesmas e não as suas sombras. E de novo os Gregos, de novo Platão, a sua dialéctica, o seu esforço de acessão de um mundo sensível - que é engano e servidão - para o mundo inteligível da luz e da verdade. Sabe-se como em Platão esse esforço de acessão é simbolizado, na bela alegoria, pelos prisioneiros agrilhoados à entrada da Caverna e que, nas sombras que ao fundo se reflectem, julgam ver o real, até ao momento em que conseguem libertar-se das cadeias e perceber, então, gradualmente, o engano em que viviam. Libertos poderão, um dia, olhar de frente o sol - razão, beleza, sumo bem. Sérgio define a emancipação como «a marcha progressiva para a liberdade; avanço definido para o eu racional, para a dessubjectivação da consciência, para a vida unitiva» $\left({ }^{9}\right)$. E as constantes referências a Sócrates e a Platão têm em Sérgio, em pleno Século XX, o sentido dessa mesma necessidade de fundamentar uma acção histórica sobre uma base irrecusável, a racionalidade, a universalidade, liberta de influências emotivas, de contingências e de paixões. O que implicará esforço e luta, mas, ao mesmo tempo uma disposição inata do ser racional para pensar a unidade. É a libertação do espírito, dentro de cada um.

De outras formas de emancipação além desta tratará António Sérgio, porque, se a libertação interior é importante, não é menos importante a libertação exterior, de formas económico-sociais caducas que urge ultrapassar; mas a libertação interior tem de vir primeiro, ela funcionará sempre como raiz, causa, condição.

A rejeição dos dogmatismos marcará o homem que se quer libertar, o que equivale a dizer que só a problemática crítica permite que o homem caminhe e fale. Não há verdadeira emancipação, portanto, sem a capacidade de problematizar criticamente, «não é a quem obedece que eu chamo escravo, mas a quem obedece sem poder julgar e poder pronunciar alto o seu juízo» $\left({ }^{10}\right)$.

O Ensaios, VII, pp. 218-219.

(i0) Democracia, p. 26. 
«O descerrar de horizontes» foi o método de Sérgio: «o quebrar de cadeias, o antidogmatismo, a problemática intérmina, o recurso incessante a experiências novas, a disponibilidade aventurosa de um pensar libérrimo» $\left({ }^{\mathrm{n}}\right)$.

Perigoso seria, nesta perspectiva, adormecer. Daí a função do moscardo - «só busco excitar o teu pensamento». Daí que o que diz, ensina, escreve, não seja mais do que instrumento de libertação, excitante, ensejo, pretexto. Porque «não trago o intento de te ser piloto»: o que Sérgio quis para cada um foi «inspirar-te o desejo de soltares amarras, de fugir do porto, de te aventurares - se pertences à espécie dos que vieram ao mundo para singrar no oceano da procura livre, entre as rajadas das opiniões, com o horizonte limpo a todos os rumos e aberto à audácia da investigação. Se assim és, amigo; se és um espírito - mete-te à vaga corajosamente e deita o meu tomo pela borda fora logo que te sintas entre mar e céu» ${ }^{12}$ ). Que o mesmo é dizer, logo que te sintas liberto das amarras que te prendem ao sensível e souberes distinguir as sombras das coisas em si.

Todo este esforço de libertação começará na escola, o que corresponderá a substituir-se uma pedagogia tradicional que é, para Sérgio, sinónimo de sabença e de sujeição à autoridade, canga contrária ao self-government entendido como única via de conquista da autonomia e de crescimento.

A sabença é «a acumulação de conhecimentos meramente recebidos, não acompanhados de actividade investigadora e de espírito crítico, da objectividade e desprendimento da atitude espiritual do criador científico» ( ${ }^{1 \mathrm{~S}}$ ).

$\ddot{E}$ todo um problema pedagógico que estará sempre subjacente ao que Sérgio propôs $\left({ }^{14}\right)$.

Dirá ele: «a doutrinação pedagógica e cooperativista é o verdadeiro fim que tenho em mente.... não é na política que eu desejaria actuar, mas sim nas escolas e cooperativas - em escolas livres e em cooperativas livres, onde os jovens e os operários se emancipassem de facto» $\left({ }^{15}\right)$.

(") Ensaios, II, p. 194.

(12) Idem, p. 198.

("1) Ensaios, I, p. 119.

(14) Disse, a propósito, Rui Grácio que a obra de Sérgio, no seu conjunto é a de um pedagogo. Joel Serrão considera que a doutrinação sergiana se não reduz à pedagogia, tendo acontecido, simplesmente que a situação portuguesa não permitiu, ao tempo, que Sérgio desenvolvesse as suas teorias em outros campos, e então o único domínio onde essa mesma doutrinação se pôde desenvolver foi o da pedagogia.

(u) Democracia, p. 317. 
Assim* as várias actividades, incluindo a política, não serão mais do que meios para atingir este fim - a educação de gente autónoma. Sem este patamar, de facto, que sociedade, que democracia possível? Que formas de pensamento e de acção possíveis?

Se toda uma pedagogia assentar naquilo a què Sérgio chama o amor pedagógico - meio para atingir o saber, a razão, amor/desejo que (como Sócrates diz no Banquete) pressupõe carência (de saber); se a educação se fizer através do entusiasmo (Sérgio cita Pasteur, falando sobre um mestre de química: "fui discípulo dos entusiasmos que me inspirou») então se excluirá certo tipo de ensino baseado na dose maciça de informação, na sabença, contrária a uma vida íntima de criação, de libertação do espírito. Em Sérgio, esta perspectiva será fundamental. Uma cultura alicerçada nesta base, a emancipação do indivíduo, irá crescer e florir em democracia. «Não sacrifico a cultura à actuação política» - dirá portanto Sérgio, precisamente porque o progresso interno é que condicionará o progresso social externo (como para Kant), porque há preeminência do moral em relação ao político, porque, ao fim, a raiz da sua obra é a reforma intelectual, sendo «a mais grave de todas as crises.... a crise da inteligência».

Emancipação, deste modo, a começar na escola; reforma, deste modo, de toda uma pedagogia: passe a escola a ser ambiente social, dê-se atenção e valor às comunidades de trabalho, porque* até aqui, «o nosso sistema de instrução só serve para fabricar parasitas» ( $\left.{ }^{\text {lti }}\right)$. Só a escola como comunidade de trabalho emancipará os jovens, possibilitando o desenvolvimento ético a par do científico, a liberdade a par da disciplina. Mas as reformas que Sérgio preconizou, neste campo, não dirão só respeito, de forma estrita, à escola, a determinado tipo de instrução, a determinados conteúdos que urge reformular-embora todos esses aspectos o tivessem preocupado. A nova pedagogia que defende terá em vista, de forma muito mais funda e completa, uma atitude intelectual, essa sim, raiz de desenvolvimento do indivíduo, nas suas várias facetas. Como se viu, essa atitude implicará uma problemática crítica, uma inquietação, um contínuo caminhar (a rejeição de dogmatismo, portanto) e resultará num processo de emancipação - «prefiro um adversário com espírito crítico ä um correligionário qiie o. não tenha».

$\left({ }^{1 \#}\right)$ Entrevista concedida por António Sérgio a «A Batalha» (1919)^ ${ }^{\wedge}$ irí Jacinto Baptista, Surgindo vem ao longe a Nova Aurora para a história do diário sindicalista A Batalha / 1919-1927,Lisboa, Livraria Bertrand, 1977, p. 179. 


\section{Claridades e Sombras}

Acima de tudo e contra tudo, que esta noção de problemática crítica vénça acanhados dogmatismos, apesar das enormes resistências que sempre se farão sentir-«nunca se acendeu um farol no mundo sem que um vento em fúria lhe soprasse em cima» $\left({ }^{17}\right)$. A ausência de tal problemática - Sérgio insiste nesta ideia - resultará no insucesso das tentativas de instauração e conservação de um regime democrático; nenhuma reforma da sociedade dependera de um «remédio mecânico», mas antes de uma «continuada acção moral», da realização da «cultura crítica, da disciplina do homem pelo seu intelecto».

\section{Democracia: Liberdade de pensamento, liberdade de acção}

Se pensar bem é importante, agir bem não o é menos, forçoso é que dos textos se passe para o mundo real: a democracia, em Sérgio, deve ser experimental e criadora, efectivando a justiça no concreto porque «os males de que nos queixamos são fatalíssima consequência da estrutura da sociedade - e só portanto terão remédio se nos metermos firmemente a transformar essa estrutura, o que não é possível com pregações - mas com reformas sociais e pedagógicas concatenadas» $\left({ }^{18}\right)$.

Teriam sido os projectos e propostas de Sérgio, nomeadamente no campo cooperativista, os mais viáveis e realistas para a necessária transformação de uma estrutura económica e social que se revelava tão arcaica? É uma questão a considerar. Mas não se poderá negar a firme disposição de António Sérgio em nunca se ficar pela especulação. Por ora é o aspecto que nos interessa salientar, a rejeição dessa atitude escolástica a que ele chama "faina em vaso fechado», o seu interesse pelo concreto, porque uma experiência de vida atribulada lhe deu «um doloroso contacto com as realidades humanas», ao mesmo tempo que a imperiosa necessidade de pensar (ordenar) com rigor as múltiplas e complexas facetas que formam e deformam o mundo onde se vive. Por isso certas épocas da história portuguesa quase o fascinaram, como a de Quinhentos, quando um espírito crítico soprou, varrendo teias e bafios, abrindo ao mundo portas e janelas, fazendo que a experiência fosse, como nunca até aí, a mãe de todas as coisas. «O verdadeiro pensamento democrático é um pen-

$\left({ }^{17}\right)$
$\left({ }^{18}\right)$
Ensaios, VII, p. 241. 
sarnento não dogmático, e a maneira experimental de proceder e a única maneira não dogmática»» $\left({ }^{19}\right)$.

Pensamento e acção em dialéctica constante (ou o racionalismo sergiano e o seu império todo poderoso coarctando um tanto o desenvolvimento dessa dialéctica?), vão caracterizar, assim, a vida e a obra de António Sérgio. Deste facto, da coordenação do pensar e do agir, resulta o tecido de relações (porque coisa alguma pode existir isolada) e a teia que Sérgio teceu entre a pedagogia, a política, a economia... $\mathrm{E}$ o todo que lhe interessa, ele refere a propósito que alguém o definiu como um homem para quem o particular não existe- não implicando esta afirmação, como se disse, falta de interesse pelo que à sua volta se passava, ou adesão à tese de Aristoteles (só há ciência do geral). A inteligência deve «apertar a teia de relações adensando o tecido cada vez mais, concretizando portanto cada vez mais» $\left({ }^{20}\right)$. Mas o universal «é o verdadeiro objecto do nosso espírito».

Pensar bem para bem agir, subordinando assim a política à pedagogia — «não há em mim um político nem aptidão para sê-lo. Sou apenas um pedagogista» $\left({ }^{21}\right)$; ou: «tenho horror à política. Digo política no sentido estrito, com carácter sectário, dos homens ansiosos de poderio e de mando. E muito em especial à da nossa terra - que parece dominada, de cabo a cabo, pela mentalidade fulanizadora da nossa gente» $\left({ }^{22}\right)$.

A um espírito mais tacanho de pequenos interesses, pequenas invejas, pequenas cobiças, Sérgio opõe uma visão alargada onde cabem, devem caber, os verdadeiros interesses que fundamentam o humanismo, a consideração dos fundamentos da democracia, alicerces que só no seu conjunto e mútua relação permitem que a existência humana como tal se justifique: não há política que sirva sem uma educação de base orientada para o respeito da dignidade humana; não há economia que resulte se não for perspectivada no conjunto dessa estrutura onde política e educação são traves mestras. Não há, em suma, cultura enraizada e em constante floração e frutificação se todos os outros elementos se considerarem desligados, sem mútuas interferências, necessárias implicações.

(Pode parecer esta batalha que Sérgio travou pela constante relacionação entre os pilares da construção social uma verdade evidente, sem novidade de maior. Sabe-se, no entanto,

\footnotetext{
$\left.{ }^{19}\right)$ Democracia, p. 98.

$\mathbf{i}^{20}$ Ensaios, VII, p. 205.

(21) Democracia, p. 306.

(22) Idem, p. 315 .
} 
como se vai sofrendo, como se continuam sofrendo os efeitos das medidas desgarradas, cada um legislando sem atender à legislação do outro, sacralizando míseros pelouros, isolando-os em torres de marfim, aí sim, abstraindo).

As «claridades sergianas» terão também a ver, portanto, com a defesa de uma cultura em aberto, porque não limitada a este ou aquele aspecto que sem o alimento vivo dos restantes aspectos forçosamente acabará por funcionar em circuito fechado, elitista. Só a constante relacionação, a consideração dessa teia cerrada, permitirá uma sociedade democrática, porque interessada nos vários aspectos que a todos dizem respeito e consequentemente interessada também no natural desenvolvimento de uma cultura em aberto. Do mesmo modo, no que respeita a educação, "a ciência, a linguagem, a ginástica, o desenho, serão considerados, na escola do futuro, como instrumentos de actividade social e subordinados, como tais, aos fins superiores da acção humana» $\left({ }^{23}\right)$. O objectivo será, assim, a formação integral do homem, a sua felicidade, que passa pelo desenvolvimento das capacidades intelectuais, mas também pela aplicação desse saber.

\section{António Sérgio, um sofista?}

Da mesma forma, o saber filosófico não deve ser fechado, reduto de especialistas alienados: Sérgio encara a filosofia como esforço para ver claro, para elucidar ideias em qualquer domínio, não devendo ser o filósofo «um retórico sobre Deus e a Alma, sobre a Essência e sobre a Existência, sobre o Infinito e o Cosmos, sobre o Mal e o Bem» $\left.{ }^{(24}\right)$.

Se a finalidade suprema for a emancipação do homem, de modo a atingir-se aquele humanismo que «não é um assum tOy mas uma atitude» $\left({ }^{25}\right)$, então os vários saberes devem, a seu modo, servir esta finalidade. A filosofia, para Sérgio, mais do que fornecer conteúdos, apuraria o espírito crítico, alertaria para a urgente necessidade de compreender o mundo pondo em evidência os seus maiores problemas, equacionando-os, com vista à solução mais correcta e mais justa, ao melhor viver. E, então, nesta perspectiva, a filosofia serviria para, estaria ao serviço de. São conhecidas as críticas ao tempo, e ainda hoje, feitas a Sérgio: a filosofia deve ser saber desinteressado, toda a cultura se deve assim caracterizar; se Sérgio considera

\footnotetext{
(23) Ensaios, I, p. 164.

C) Idem, VII, p. 234.

( ${ }^{25}$ ) Idem, p. 235.
} 
a filosofia de forma pragmática, se ele subordina o conhecimento a fins utilitários, se o social e o político prevalecem e surgem sempre em articulação com a filosofia, se a filosofia se reduz a uma pedagogia - que independência para o filósofo? Responde Sérgio: «Não pode o conceito de pedagogia ser identificado ao de pragmático.... ele não se opõe de maneira alguma à ideia de cultura desinteressada do espírito.... para mim pedagogia e cultura são a mesma coisa - não porque reduza a minha noção de cultura a uma ideia acanhada da função pedagógica, senão porque dilato a minha concepção à largura máxima da noção de cultura» $\left.{ }^{26}\right)$.

Mais importante que o peso dos saberes, que a quantidade substancial de informação é, para Sérgio, a atitude desperta e vigilante, a capacidade de cada vez melhor, o homem se ir compreendendo e ao mundo que o rodeia. É de facto uma questão de qualidade, uma questão ética, se se preferir; é um firme empenhamento na construção de certo humanismo que, para o ser de facto, implica que o saber não sacrifique o ser nos altares suspeitos da desencarnada sapiência. Por isso Sérgio se interessa por uma pedagogia que é muito mais do que ideia acanhada de um acertado exercício escolar, antes visão ampla de como caminhar no mundo. É neste sentido que ela se encontra com a filosofia. O saber contra o ser, a informação contra a formação, os assuntos contra as atitudes: "o universo das escolas é um andaime de abstracções: nada de formas, de rumor, de lidas. Não espereis encontrar nelas o que encontrais na sociedade: comparai as preocupações da sociedade com as lições do professor, a actividade do mundo real com a actividade estudantil, um problema da vida adulta com um problema discutido em aulas - e vereis aue os dois mundos se não correlatam. Educar uma criança enviando-a à actual escola é como preparar um automobilista metendo*-o no museu dos coches reais» $\left({ }^{27}\right)$.

A questão não é pacífica: trata-se de apurar se, no caso da filosofia, ela terá de ser, e só, construção teórica de um saber específico na ausência de qualquer pragmatismo ou mesmo na ausência de tonalidade pedagógica (na acepção e com as dimensões que Sérgio encontrou para a pedagogia), ou se a permanente busca de uma atitude marcará, mais do que as aquisições teóricas, tal saber. Sérgio optará, como se viu, por uma fillosofia que, não sendo propriamente pragmá-

(*) «Notas de esclarecimento», Portucale, Porto, Janeiro-Junho 1950, pp. 22-23.

$\left.{ }^{27}\right)$ Ensaios, I, p. 177. 


\section{Claridades e Sombras}

tica, estaria no entanto ao serviço do homem, quer dizer, da sua promoção, do seu crescimento, da defínição do seu lugar entre os outros, entre as coisas. (Se a opção sergiana por uma forma de racionalismo neo-kantiano, com exclusão de outras formas de conhecer, é a mais propícia a esta promoção e autonomia, é outra questão). Uma filosofia a permitir que todos os outros saberes se redefinissem, que a visão do mundo se alargasse na relacionação que, à luz de um saber (filosófico), de uma atitude (de indagação constante de todas as coisas), forçosamente se estabeleceria. Filosofia que, a ser desta maneira, se não cingiria ao aprofundar, até às últimas consequências, de questões puramente teóricas, embora as não excluisse, pela única razão de que as questões fundamentais que motivam qualquer reflexão, de uma forma ou de outra, à vida do homem e ao seu mundo estão ligadas, ele viverá delas se alimentando e os seus actos e movimentos hão-de reflectir, necessariamente, a forma como estas questões fundamentais foram pensadas. Não será crível que a reflexão sobre uma qualquer questão fundamental, feita a nível filosófico, não modifique $\mathrm{o}$, viver de um homem, o seu posicionamento frente ao mundo. E neste sentido que Sérgio dirá que a filosofia imbrinca sempre com questões de variada ordem. É neste sentido que a filosofia hoje caminha? E deixará, por isso, de ter um estatuto próprio? Não acontecerá o mesmo, afinal, a todos os outros saberes? O que há verdadeiramente que se possa considerar isolado, sem interferências de ordem variadíssima? Será hoje Sérgio condenado à beberagem mortal, como foi Socrates, por buscar como finalidade suprema para o homem o seu bem, a sua integridade? Por considerar que não há saber que se não deva humanizar? A questão que, a propósito desta tomada de posição sergiana se levanta (recusa do filósofo como retórico, enredado em abstracções desencarnadas; recusa de uma escola (mal) alimentada por essas mesmas abstracções) - não é de muito fácil resolução: porque os partidários de um intelectualismo todo poderoso, única pedra de toque de ascensão à cátedra - aspiração máxima - vêem com maus olhos a «teia de relações» sergiana (pedagogia, política, cultura e a filosofia pairando, indistinta, sobre tudo isto!). Há que manter, nesta óptica, um estatuto muito firme e delimitado de ciência e depois, dentro dos muros da construção, trabalhar a fundo no sistema. As grandes filosofias sistemáticas, sabe-se, assim procederam. Portanto Sérgio não teria sido filósofo, porque não foi sistemático.

Temos, em suma, que a busca de uma atitude humana de indagação crítica (com a consequente carga de criatividade que provoca), se for objectivo essencial da filosofia, como em 
Sérgio, se lhe for atribuído maior valor que às possíveis conquistas que fizer, é tida como atentória dos valores perenes dessa mesma filosofia, atentatória dos valores de almejadas sapiências - que não de socráticas sagezas.

Filosofia ao serviço do homem, filosofia que é pedagogia, filosofia que serve para elucidar ideias em qualquer domínio, tão crítica que, na perspectiva sergiana, os próprios filósofos se devem reler à luz de uma época (problema tratado em Cartésianisme Ideal e Cartesianismo Real) - a partir destas e outras noções semelhantes se levanta a suspeita de um Sérgio sofista. E, no entanto, que diferença a separá-los; de um individualismo anarquista a um individualismo racionalista, social, como aconteceu também relativamente a Socrates, quando o método do pedagogo vai revelar a existência da razão comum e então "construir o alimento da filosofia.... foi construir o da pedagogia e ao mesmo tempo o da sociedade» $\left({ }^{28}\right)$.

De resto, as semelhanças e influências que vulgarmente se encontram entre o pensamento de Sérgio e o de Sócrates (Platão), logo nos elucidam sobre se poderemos apelidar Sérgio de sofista, sabendo como Sócrates considerava e criticava os sofistas, a certa superioridade de mercenários, a técnica usada para a transmissão de verdades feitas: «Mas, Hipocrates, um sofista não é precisamente um homem que faz comércio das mercadorias de que a alma se alimenta?» $\left({ }^{29}\right)$.

\section{O RACIONALISMO SERGIANO}

Alvorada, claridade, luz! De ti, luz, tenho sede agora: de luz absoluta, de luz perfeita! Faze-nos ver, luz do sol, não fantasmas mas ideias; varre as ilusões que nos prendem a alma, torna-nos claros e livres em ti!

Os meus pensamentos são labaredas... agitadas por ventos desencontrados na fornalha tonta da imaginação.

António Sérgio, Antigona

Embora seja difícil dar uma noção unívoca de racionalismo, dado que através dos tempos este conceito tem sofrido alterações, poder-se-à dizer que, de uma forma geral, 1967, p. 45.

$\left.C_{29}^{8}\right)$ Ensaios, I, p. 135.

$\left.i^{29}\right)$ Platão, Protágoras, 313 c, Paris, Garnier-Flammarion, 
o racionalismo se caracteriza por ser doutrina que faz da Razão a base de todo o conhecimento e que tem como finalidade a ordem, a transparência, em oposição ao conhecimento confuso que os sentidos permitem. A razão contém em si os germes do conhecimento, independentemente dos contributos da experiência. Há, portanto, nesta perspectiva, uma prioridade da razão sobre a experiência sempre contingente; o inatismo cartesiano, o a priori, o transcendental e o tema platónico da reminiscência remetem para tal concepção.

A razão será, assim, identificada com a própria inteligibilidade, com a ordenação existente, tanto nas ideias como nos seres, e que permite se efectuem, de maneira sistemática, conjuntos de operações com alcance universal.

Para Sérgio, da mesma forma, a Razão, valor supremo, e princípio de universal inteligibilidade, é uma força de ordenação interna (espiritual), «uma tecedora de relações recíprocas», e é criativa, no sentido em que a inteligência do homem «a si mesmo se não adora, mas sim se observa e se corrige» $\mathrm{t}^{30}$ ). Por isso o próprio Sérgio se autodenomina de neo-kantiano no seguimento da tendência mais racionalista, conceptualista, objectivista e cientificista (que era a tendência da escola de Marburgo que tinha como modelo a ciência físico-matemática ).

Diferentemente do racionalismo tradicional a razão não é em Sérgio uma substância mas uma actividade que se irá exercer também na esfera do concreto.

O racionalismo sergiano seria a um tempo psicológico - a razão é superior à emoção; gnoseológico - o único órgão adequado ou completo do conhecimento é a razão; metafísico - a realidade é de carácter racional. E assim sendo, poderemos dizer que Sérgio usou e abusou da razão (porque uso simples da razão fizeram-no também os empiristas modernos).

A tradição racionalista vem de longe, é uma escolha grega de há 24 séculos que acaba por identificar verdade, ser e racionalidade (como acontece em Platão). Esta razão, este logos (discurso coerente), une desde o início a linguagem à razão e sabe-se como toda a prática socrática se desenvolveu neste sentido; também aqui António Sérgio é um discípulo dos gregos.

Mais tarde, já nos tempos modernos, Descartes, Malebranche, Espinosa, Leibniz, continuam, de forma mais complexa, todo um trabalho de racionalização da realidade.

$\left(^{30}\right)$ Ensaios, II, p. 26. 
Antonio Sérgio, embora cite com frequência a herança platónica, cartesiana, kantiana, situar-se-à muito mais num racionalismo do século XVIII, fazendo a apologia de uma razão que é atitude epistemológica e que é, de igual modo, directriz para a acção moral e social. Porque quanto ao racionalismo do século XVII, de tipo cartesiano, não se consegue este furtar a suposições e fundamentações metafísicas, embora Sérgio, admirador incondicional do "grande mestre Descartes», busque engenhosas maneiras de o «desculpar», por recorrer ele a Deus como princípio e garante de verdades que à razão - e pareceria que só a ela - competia fundamentar (Cartésianisme Real e Cartesianismo Ideal).

A Razão, como princípio de universal inteligibilidade, opõe-se em princípio ao empirismo que rejeita as hipóteses a priori, porque defende que os nossos conhecimentos são aquisições da experiência. As posições radicalizadas foram no entanto repensadas por Kant e as oposições muito marcadas entre empirismo e racionalismo, atenuadas: a experiência passa a ser considerada não como um dado, mas como uma construção que resulta da actividade das categorias do entendimento (formas) e dos conteúdos da sensibilidade (matéria). Há assim como que uma síntese feita por Kant entre empirismo e racionalismo, sendo o conhecimento empírico um composto de impressões sensíveis e elementos subjectivos que se apresentam sob forma de condições a priori do conhecimento, e portanto o objecto do conhecimento é sempre uma síntese. Dirá Sérgio, também: «na experiência humana nunca há só sentires, como nunca só ideias, senão que sempre a íntima ligação vivaz de quaisquer sentires com quaisquer ideias» $\left.{ }^{3 R}\right)$.

O método transcendental kantiano desenvolverá, como se sabe, todas as consequências deste princípio, na base de que esta síntese surge desde o primeiro nível de conhecimento, quando o espírito entra em relação com os objectos, aplicando desde logo as intuições puras (a priori) de espaço e de tempo, que não são portanto seres reais. Tal como Kant, dirá Sérgio: «Para o idealista crítico, que sustenta a tese da idealidade do espaço, a mente fabrica e não absorve; para o realista, o intelecto é sobretudo um absorvente, uma espécie de reflector de uma realidade «externa». Para o idealista, o espaço é uma construção ideal do intelecto. A divergência.... é a de um rea-

( $\left.{ }^{31}\right)$ «Notas de esclarecimento», Portucale, p. 199. 
lismo do senso comum para um idealismo epistemológico, racional e crítico» $\left({ }^{32}\right)$.

Assim parecem resolvidas as dificuldades do empirismo, ou seja, a impossibilidade de uma universalidade e necessidade que as leis científicas exigem, e também as dificuldades do racionalismo no que respeitava ao ajuste das proposições científicas aos dados empíricos.

A chamada revolução coperniciana, a propósito desta solução proposta por Kant, remete para a inversão de perspectivas: o conhecimento já não é considerado do ponto de vista da realidade, mas a realidade é que é vista na perspectiva do conhecimento, evitando-se assim os escolhos quer do dogmatismo, quer do cepticismo.

$\mathrm{O}$ ponto de partida para a reflexão será portanto o $e u$, a representação do mundo e não o próprio mundo; a desconfiança em relação a todo o real é maior em Kant do que em Descartes, onde se insinuam resíduos realistas, maior em Fichte - nos post-kantianos de uma maneira geral — do que em Kant, que fala ainda na coisa-em-si. E, como se sabe, a revolução idealista, a opor-se firmemente ao realismo (no sentido gnoseológico), a opor-se também firmemente ao materialismo (no sentido metafísico). Uma revolução que, entre o século XVIII e o século XIX, visa, acima de tudo, numa dimensão ética, precisar o sentido do homem e do seu destino e também o sentido da existência social.

Sérgio, idealista, defenderá igualmente a capacidade criadora do sujeito na linha de todo o idealismo (e até do próprio materialismo dialéctico, razão por que dirá que, ao fím, esta forma de materialismo será também um idealismo - «pautar a evolução do mundo real por um jogo dialéctico de ideias é ser-se de facto idealista, é ser-se idealista o crer que a evolução encaminhará os homens - por sua própria legislação intrínseca- da necessidade para a liberdade») ( ${ }^{33}$ ); e defenderá que o entendimento tem o máximo de espontaneidade na criação do saber, que ele é inteiramente livre, a verdade encontrar-se-á nas ideias e na relação entre as ideias. A autosuficiência da razão é assim levada às últimas consequências e por isso Magalhães-Vilhena dirá que «a iniciativa psíquica em Sérgio apresenta-se como começo absoluto e não como uma resposta cerebral e psíquica a excitações e solicitações

$\left(\begin{array}{l}32 \\ 33\end{array}\right)$ Ensaios, VII, p. 212.

(33) J. J. Rousseau, Emílio, Lisboa, Cadernos Culturais «Inquérito", 1940 (excertos seleccionados, traduzidos, anotados, e prefaciados por António Sérgio), p. 60. 
externas» $\left({ }^{34}\right)$. E se Sérgio admite a existência de algo independente da psique - «nunca duvidei, em momento algum, da existência do que se designa por mundo exterior quer dizer: de um algo independente da nossa psique, de uma realidade física, de uma Físis» - o certo é que afirma «que nenhum facto existe como um dado puro anteriormente à ideia e é nas ideias e pelas ideias que nós apreendemos um facto qualquer.... O facto sensível, desde o princípio, é uma espécie de entroncamento de relações actuantes, que o pensar determina cada vez mais, ligando ao conjunto cada vez mais ideias» $\left({ }^{35}\right)$.

Sabe-se das dificuldades em explicar, segundo tal perspectiva, a existência de um mundo anterior ao pensamento. $\mathrm{O}$ objecto será, para Sérgio, sempre um objecto do pensamento, a verdade não é o acordo da ideia com a coisa (porque não há o absoluto da dita coisa), é uma harmonia progressiva de ideias.

E por isso Sérgio, tão próximo de Kant, «construí livremente o meu platonismo próprio (que resultou kantiano)» $\left({ }^{36}\right)$ - , em alguns pontos se distanciará dele, como por exemplo, na consideração kantiana de coisa-em-si, ou seja, daquelas realidades que, segundo Kant, se não podem conhecer por se encontrarem fora dos limites da experiência possível, sem validade objectiva. Para Sérgio, "pôr uma Estética antes da Analítica é fazer começar o pensamento na intuição sensível, em algo que está fora do pensamento e desvalorizar o acto criador que é o juízo; fixar as categorias é limitar o poder criador do intelecto». E, assim, Sérgio conclui que o «Kantismo ideal» - contrariamente ao real, ao realmente acontecido «seria o que começasse pela Analítica; o que rejeitasse a coisa-em-si») $\left.{ }^{37}\right)$.

Será, em suma, a luta da ideia contra a imagem - luta que, de certo modo, vem já de Platão, que com intensidade se desenvolve em Descartes, Malebranche, Espinosa, que fará Sérgio manter polémica acesa contra Bento de Jesus Caraça, por exemplo, por o racionalismo deste não desprezar a intuição sensível. Ora as intuições sensíveis para Sérgio serão sempre consideradas como "elementos que na experiência são inseparáveis das ideias», na base de que a experiência nunca é

$\left.{ }^{34}\right)$ Magalhães-Vilhena, António Sérgio - o Idealismo Crítico e a Crise da Ideologia Burguesa, Lisboa, Ed. Cosmos, 1975, p. 46.

${ }^{35}$ Ensaios, III, p. 228.

(36) «Notas de esclarecimento», Portucale, p. 216.

$\left({ }^{37}\right)$ Ensaios, VII, p. 190. 
matéria-prima, mas já um produto, nunca é mãe - no dizer crítico de Eduardo Lourenço- mas, em Sérgio, sempre filha da razão.

Temos pois que em Sérgio o intelecto é que dá sentido às coisas, a Razão é princípio de universal inteligibilidade, o verdadeiro eu profundo é racional, o real é claro, transparente. E o homem será uma consciência na claridade (Eduardo Lourenço), consciência que sobrevoa as próprias coisas, contrariamente ao que afirmava Bergson. A imagem terá, assim, de ser recalcada, é a «iconoclastia da imagem» (Gilbert Durand).

Durante longos séculos foi esta a tradição da Europa, toda uma pedagogia a ela estará ligada, na base de que interessa mais estabelecer o que é o homem como consciência, do que o homem como existência. Interessarão as claridades, não as sombras. E se Descartes duvida, é ainda pelo reino da luz que essa dúvida perpassa, dúvida metódica, geométrica, resolvida depois a contento da razão. O homem estabelece-se, assim, frente a um mundo sentido como adverso, caverna povoada por sombras enganosas, sereias tentadoras a esconjurar. $\mathrm{O}$ quebrar dessas cadeias corresponde à libertação do mundo sensível e corresponde também a uma procura que, segundo (certo) Platão, segundo Sérgio, segundo todos os racionalistas extremos, terá de ser feita recalcando a imagem, o símbolo. Mas Platão é ainda um caso à parte, sabe-se da importância dada ao mito nas suas doutrinas: Apoio domina mas Dionísio, à sua maneira, dominará também. Há claridades, mas há sombras procuradas e mantidas. De Aristoteles e S. Tomás de Aquino a Descartes, a tendência racionalista acentua-se porque «a imaginação vai estando cada vez menos no poder» (Gilbert Durand). Nos nossos dias um Brunsvicg continua uma tradição que Sérgio adopta sem ambiguidades.

A Alegoria da Caverna elucida muito bem, de resto, esta posição de confronto entre o homem e o seu mundo directo - homem que, por assim dizer, é portador de luz e de verdade, mundo que está mergulhado em trevas e enganos. Confronto que resultará, inevitavelmente, em dualismo. É fácil percebê-lo em Sérgio, a todo o momento-por exemplo, quando fala num Antero luminoso e num Antero noctumo.

A questão que se levanta é, afinal, a seguinte: o chamado «humanismo criativo» (Barahona Femandes) de Sérgio, alimentado pela razão e só por ela, será um verdadeiro humanismo? Será completo? Teria sido Sérgio um homem completo ao sobrevalorizar de tal forma a razão, ao considerar que só o intelecto é que dá sentido às coisas? Que 
vantagens ou desvantagens advirão para o homem se, em vez do dualismo homem racional/mundo sensível, ele aceitar e se comprometer numa visão dialéctica alargada e englobante, onde as intuições sensíveis possam ser, igualmente, ponto de partida? O mesmo é perguntar se, além da razão clássica, não haverá outras razões possíveis? Outras ordens possíveis? Interrogações estas que, como se sabe, começaram a ter uma insistência cada vez maior a partir do século XIX: então assiste-se, pode dizer-se, à destruição da antiga autoridade considerada em aspectos e domínios diversos. E acusa-se geralmente Sérgio de, um tanto orgulhosamente, ter sobrevoado, alumiado (ou encandeado?) com a luz da sua própria razão soberana, as contradições que começavam a assolar uma Europa dividida, enfraquecida por duas guerras devastadoras; contradições de que doutrinas como o existencialismo, movimentos estéticos como o surrealismo, com a consequente ressurgência do mito, da força do símbolo, reflectem.

É, então, o sentido da própria existência humana que se procura quando se afirma que de nada podemos ter certezas fundas, quando se repensam responsabilidades e quando a ansiedade cresce moldando doutrinas sombrias. Por isso o existencialismo e também, por outras razões, o positivismo lógico, serão sobrevoados por Sérgio: nem o que é sombrio e não obedece à «longa cadeia de razões», nem o que se desenvolve na base de um certo empirismo, pode dar conta e satisfação dessa racionalidade que é única fonte e único critério.

E, no entanto, diz Jaspers: «Silenciosamente alguma coisa de enorme aconteceu na realidade do homem ocidental: uma destruição da antiga autoridade, uma desilusão total numa razão superconfiante e uma dissolução de laços, fizeram que tudo, absolutamente tudo, pareça ser possível») $\left({ }^{38}\right)$.

No domínio da ciência sabe-se como, a partir dos fins do século XIX, uma epistemologia clássica vai perdendo terreno, e as certezas fechadas vão sendo substituídas pelo provisório; hoje fala-se em paradigmas (Kuhn), que são determinadas maneiras de ver o mundo, resultados científicos fundamentais mas que mantêm sempre uma conclusão em aberto: assim de um paradigma se pode passar a outro, e só periodicamente o paradigma deixa de suscitar oposições, provoca até certa resistência às inovações, podendo considerar-se o

${ }^{(38}$ ) James Joli, A Europa desde 1870, $\mathbf{1 .}^{\text {a }}$ ed., Lisboa, Publicações D. Quixote, 1982, p. 466. 


\section{Claridades e Sombras}

principal responsável por um dogmatismo à tradição preestabelecida. Na nova concepção de epistemologia, a teoria será verdadeira só enquanto resistir à refutação; e a procura dos fundamentos para a ciência é doravante rejeitada (Popper e Kuhn). E portanto hoje, para a ciência (ou para alguns cientistas), o caminho da diversidade, do risco, do parcial, do provisório, da pesquisa. (Ou, se não quisermos ir tão longe, é o problema da substituição de uma teoria por outra teoria o que, hoje, preocupa os cientistas, mais do que a busca da coerência interna). Por vezes até, o que seria seguramente considerado herético por Sérgio, há sombras míticas nas proximidades da ciência, como François Jacob nos diz em $O$ Jogo dos Possíveis: Por exemplo, as novas descobertas sobre o DNA recombinante (tirar genes de um organismo para se implantarem num outro) - e os angustiados temores de que nasçam monstros híbridos. É evidente que a ciência procura a objectividade - que hoje no entanto já tem outro sentido, a antiga objectividade «pesada» deixou de se considerar na nova física - e rejeita o mito: mas a consideração de que ele se pode aproximar da ciência, ameaçá-la, é já de si sintomática. Hoje, cientistas como Jacob não têm a obsessão das verdades absolutas e imóveis (recordemos as formas platónicas de Sérgio ou, se quisermos, as estruturas invariantes) e arriscam-se a dizer: "Claro está que a ciência se esforça por descrever a natureza e discernir entre o sonho e a realidade. Mas não devemos esquecer que o ser humano tem, provavelmente, tanta necessidade de sonho como de realidade», porque, «mítica ou científica, a representação do mundo que o homem constrói tem sempre grande parte da sua imaginação» $\left({ }^{39}\right)$.

Destruição da antiga autoridade, como diz Jaspers? Desilusão numa razão superconfiante? A Alice de Lewis Carroll dirá que «não se pode acreditar em coisas impossíveis». Mas a rainha responde-lhe — «suponho que tens falta de treino, aconteceu-me algumas vezes acreditar em seis coisas impossíveis antes do pequeno almoço»».

Além da clássica, haverá outras razões possíveis? O certo é que tanto a explicação da natureza como a explicação do prónrio homem, têm sofrido profundas alterações, rupturas se produzem, os insucessos sobrevêm, fenómenos complexos surgem que as velhas categorias já não comportam. A visão do mundo da época de Kant é posta em causa, as formas a priori da sensibilidade já não são aceitáveis na física de

$\left.{ }^{30}\right)$ François Jacob, O Jogo dos Possíveis, l. ${ }^{\text {a }}$ ed., Lisboa, Publicações Gradiva, 1982. 
hoje. A partir dos fins do século XIX os cientistas encaram a ciência de outra forma, já não, como até aí, acima das incertezas e dos conflitos da vida de todos os dias. Princípios considerados de fundamental importância, fundamentos sólidos, vão ser de facto profundamente abalados; até ao século XIX a ciência assentava no princípio do determinismo, considerando que os processos da Natureza consistem num rigoroso encadeamento de causas e consequências, nada acontecendo de incerto e de indeterminado na natureza, só a ignorância sendo responsável pelas incertezas. $\mathrm{O}$ próprio espírito de exactidão da ciência - só o que é mensurável é susceptive! de estudo exacto, o objectivo da ciência é medir os fenómenos, é descrever através de números, é estabelecer relações precisas - acentua a força da universal inteligibilidade. A estes dois princípios ainda se poderá acrescentar o princípio da continuidade - os movimentos da natureza produzem-se gradualmente: entre dois momentos considerados, entre duas posições, existem sempre outros momentos. Além de que o cientista era mais um instrumento ao serviço da natureza, orgulhava-se em vincar a sua impessoalidade, a não interacção do homem que investiga e do fenómeno investigado.

O cientista do século XX é protagonista de todo um processo de revisão: em vez de certezas absolutas, uma margem de incerteza, em muitos domínios; em vez do determinismo, do encadeamento causa-efeito, a certeza de que as mais pequenas unidades de matéria e de energia só podem ser descritas em termos de probabilidade, as previsões rigorosas neste campo não passando de quimera. A quantidade, por sua vez, será substituída pela análise estrutural, a continuidade pela estrutura descontinua do universo. Considera-se, além disso, que as operações do observador não se podem considerar isoladas de fenómeno observado. Acentua-se cada vez mais o papel criador, a actividade do cientista, e uma dose de acaso introduz-se nas teorias científicas da física actual (sem que se possa dizer que, por isso. os modos de raciocínio sejam menos científicos). A ordem encontrada hoje na Natureza é só uma das muitas ordens possíveis. E o real, deixa de ser transparente, para se tornar velado.

As próprias concepções de espaço e de tempo ilustram, de forma vincada, os golpes que uma epistemologia e uma filosofia clássicas sofreram: é toda uma relativização do real, uma subversão do tempo e do determinismo causal que levam Gilbert Durand a supor que, por isso, as ciências do homem vão entrando em consonância cada vez maior com as chamadas ciências exactas. E, em ambos os saberes, «o mitema da profundidade» contra a linearidade, a transformação de um 
espaço homogéneo em espaço qualitativo (que a psicanálise exemplifica); e também a transformação de um tempo linear, irreversível: a síncrono cidade (Jung) implica o abandono de noções clássicas de causa e efeito: a esta nova luz, o efeito reforça a causa, a causa torna-se efeito do seu efeito-e isto tanto é válido para a ciência mais exacta, hoje, como o é para os fenómenos humanos. A relação de incerteza que se estabelece a partir de tais concepções de tempo e de espaço pertence ao domínio dos fenómenos puramente humanos, como ao das ciências «exactas» e não pode ser explicada na base das coordenadas cartesianas. O tempo e o espaço, como concepções únicas e globais, são, segundo Michel Serres, artefactos filosóficos. Deve falar-se, antes, em proliferação múltipla dos espaços, como nos mostram as geometrias não-euclidianas - a Topologia «e o desdobrar dos espaços caóticos, densos, compactos, conexos, com análises do contínuo dos intervalos, dos bordos...» $\left({ }^{40}\right)$.

Assim a ciência dos nossos dias se afasta das concepções lineares, se afasta de claridades racionais por onde não perpassam dúvidas que a essas mesmas claridades racionais digam respeito. (O físico Bernard D’Espagnat dirá: «O mito de Prometeu, o mito do paraíso terrestre e o modelo planetário do átomo - o modelo de Niels Bohr - são absolutamente semelhantes»). E enquanto a ciência se afasta de tais concepcões clássicas, se aproxima, segundo ainda Gilbert Durand, do mito, porque neste domínio as concepções de espaço e de tempo (Eliade e Lévi-Strauss falam-nos disso) são semelhantes às que encontramos hoje nos conceitos epistemológicos de tempo e de causalidade reversíveis. Assiste-se, nas correntes literárias e estéticas dos fins do século XIX, à ressurgência do mito que representaria o equilíbrio ameaçado pelo desenvolvimento da indústria e da tecnologia: Nietzsche e o mito de Zaratustra são um grito contra o racional, a ordem e o quantitativo - e este é um entre muitos exemplos possíveis.

$\mathrm{O}$ desenvolvimento da antropologia (O Pensamento Selvagem de Lévi-Strauss) põe em evidểncia novas formas de possível estruturação mental do real, não mais se aceitando as designações pejorativas de civilizações primitivas, de pensamento ${ }^{1}$ pré-lógico; a lógica tradicional bivalente é posta em causa e passam a ter aplicação e importância cada vez maior as lógicas polivalentes. E é curioso verificar como, dentro do próprio marxismo, na escola de Frankfurt, há autores que se

$\left({ }^{40}\right)$ Michel Serres, Le Passage $d u$ Nord-Ouest, 1. ${ }^{\text {a }}$ ed., Paris, Les Editions de Minuit, 1980, p. 69. 
apercebem e aceitam as estruturas míticas, como H. Marcuse, Manheim, Ernst Bloch. Por isso Durand pergunta, na linha de Dumézil, se a própria história, hoje, não será ela um conjunto mitologizante de interpretações... o que corresponderá à dúvida, nada cartesiana, sobre a validade de uma certa positividade na interpretação da história e a validade dos movimentos míticos do pensamento humano. Haverá, segundo estes autores, «precipitados míticos» na história - como é o caso do hitleranismo, da execução de Luís XVI, do Terror. Concepções estas que estão muito longe, é evidente, das perspectivas sergianas: "o sentir é um nã̃o sei quê imensamente indistinto; o objecto correspondente é uma construção mental em que a actividade agregadora e arquitectora do intelecto aplica à sensação as suas relações categoriais; a de um-e-múltiplo; a de substância-e-qualidade; a de causa-e-efeito; a de parte-e-todo» $\left({ }^{41}\right)$.

Só na primeira infância, para Sérgio, os sentires (sensações mal organizadas) acontecem como produto da actividade sensorial-motriz; os outros níveis de actividade do intelecto irão diferenciando sujeito e objecto e possibilitando a constituição das operações lógicas reversíveis, com a utilização de conceitos categoriais e a invenção de hipóteses; só no adulto este nível formal, com os seus aspectos operacionais se encontra em perfeito desenvolvimento; quanto ao primeiro nível, o dos sentires quando ainda não há construção mental, ele é só uma primeira fase do desenvolvimento humano e, claro, a menos importante. Falar-se de «precipitados míticos», interpretações mitologizantes, relações de incerteza, com as suas margens de bruma; falar-se em forças inconscientes, irracionais, em espaço qualitativo, em tempo reversível, e falar-se na soberana e iluminada (e kantiana) actividade do intelecto aplicando à sensação as suas relações categoriais, é. de facto, situarmo-nos em territórios que nada terão de comum com a perspectiva sergiana.

A ciência de hoje - aliás toda uma cultura - não reieita, é evidente, a necessidade imperiosa de uma razão ordenadora; só que é talvez mais humilde na convicção de que, em termos de profundidade e não de linearidade, se não pode estar tão seguro, como estava Sérgio, de oue certa vaga de mistério, de indecifrável, de inquantificável, não se insinue por entre as claridades da razão, tornando-a, por isso, mais vulnerável e muitíssimo mais distante da objectividade requerida por Galileu, Descartes, Newton.

$\left({ }^{41}\right)$ Cartas de Problemática, n. ${ }^{\circ}$ 3, Lisboa, Inquérito, p. 3. 
Sabe-se que tais afirmações repugnavam ao autor dos Ensaios. Barahona Fernandes diz, a propósito: «....não seria difícil imaginar o que Sérgio diria por exemplo da obra de Foucault «Les Mots et les Choses» ou dos «Écrits» de Lacan (sabido como lhe repugnavam as interpretações simbólicas e fantasmáticas.....)» $\left({ }^{42}\right)$.

$\mathrm{O}$ racionalismo sergiano percorre um espaço limitado, círculo fechado a não permitir a entrada de zonas de penumbra com os seus discursos não unívocos. E essa racionalidade que recusa as sombras é, por isso mesmo, extremamente sombria. Mas como essas zonas existem e se impõem, quer Sérgio as aceite, quer não, o dualismo surge: a alegoria platónica da caverna será a imagem exemplar de uma separação entre dois mundos, de um corte voluntário, de uma escolha: a luz é a verdade, é a inteligibilidade, é a razão assumida. As sombras terão, portanto, de ser recusadas como contrárias e nefastas à razão, nunca englobadas como necessárias ou como fundamento do próprio processo racional. Nesta linha se recusa a própria infância, com as suas significações fenomenológicas, - «recordo pouco o passado», «sou um homem que esqueceu o passado») (como várias vezes refere na entrevista, gravada em disco, concedida a Igrejas Caeiro). Nesta linha se recusa um nível-fundamento $\left({ }^{43}\right)$, ligado ao inconsciente (colectivo e específico), nível de implicações míticas onde a não racionalidade atinge o seu máximo. Mas em Sérgio a abertura tem um único sentido, em direcção ao nível racional — da conceptualização, do logos, da pedagogia, da ideologia.

O círculo sergiano começa e acaba na razão.

Existem ouras propostas, contudo, mais englobantes, mais dinâmicas, mais ricas, permitindo circuitos constantes entre forças não-racionais e outras onde se atinge o máximo de racionalidade, movimentos que alternam entre uma desqualificação progressiva das conceptualizações (quando se atinge a zona profunda das implicações míticas) e a racionalização progressiva do mítico (até que se chegue ao máximo de racionalidade na zona dos discursos unívocos). Afinal, «a razão e a ciência não ligam os homens senão às coisas, mas aquilo que verdadeiramente liga os homens entre si, ao nível humilde das alegrias e das tristezas quotidianas da espécie

$\left({ }^{42}\right)$ H. J. Barahona Fernandes, «As estruturas do intelecto segundo as "Cartas de Problemática» de António Sérgio», Memórias da Academia das Ciências, 1969, p. 161.

$\left({ }^{43}\right)$ Gilbert Durand, "Le renouveau de l'enchantement», Cadmos-Cahiers Trimestrels de L'Institut Universitaire d'Etudes, Genève, 1982. 
humana, é essa representação afectiva, porque vivida, que constitui o império das imagens»» $\left({ }^{44}\right)$. Talvez que razão e ciência liguem os homens, não só às coisas, como diz Durand, mas também aos outros homens, há toda uma humanização da ciência que é importante considerar, Sérgio insistiu nesse aspecto. E, portanto, não se pretende diminuir o valor de todo um pensamento crítico, de uma racionalidade a muitos títulos indispensável. Mas considera-se que, paralelamente ao lugar que a razão ocupa, a imaginação tem que ocupar também o seu próprio lugar porque o objectivo que o homem e a sociedade devem procurar é o equilíbrio - biológico, psicológico, sociológico. A imaginação que não é «fornalha tonta», contrabalançando o pensamento crítico, permite esse equilíbrio.

Além da Física e da Matemática, que nortearam todo o pensamento de Sérgio, outras ciências e saberes contribuirão para este equilíbrio - a etnologia, a sociologia, a psico-patologia, as mitologias, a literatura, a estética...

A razão tem as suas exigências e não se pode compadecer com infiltrações ambíguas, embora, como se viu, as sombras do mito possam, em certos casos aproximar-se da ciência. Dir-se-á, contudo, que será sempre fácil distinguir a teoria - que cede diante do facto experimental contrário, e o mito que não cede; será fácil distinguir entre o modelo (concretização de uma teoria abstracta) que é parcial, incompleto, provisório - e o mito que, como a crença, é total e definitivo.

Para Bachelard, uma das exigências da razão será precisamente a «psicanálise objectiva» a necessária libertação da imagem, do «fantasma da imagem», de tudo aquilo que não apresenta nitidez e rigor. Mas este epistemólogo que defende o «materialismo racional», não aceita, ao contrário de Sérgio, que o verdadeiro eu profundo seja só o eu racional e defende outros domínios de expressão incompatíveis com o método das ciências da natureza, porque relacionados com um objecto que é sentimental e afectivo. Por isso ele diz que «os eixos da ciência e da poesia são inversos» e fala da rivalidade entre a actividade conceptual e a actividade imaginativa: mas, para o homem, as funções verdadeiramente humanizantes terão de passar por estes dois meios de transformar o mundo- a objectivação da ciência e a subjectivação de todo um imaginário, esta última feita através da fenomenologia que capta nas imagens «o próprio ser da sua originalidade» e beArcádia, 1979, p. 128.

Gilbert Durand, A imaginação simbólica, 1. ${ }^{\mathrm{a}}$ ed., Lisboa, 
neficia assim «da mais ilustre produtividade psíquica que é a da imaginação» $\left({ }^{45}\right)$.

Não é o reino da psicanálise, que Sérgio também afastou; é, para Bachelard, o reino da super-consciência, não dos sonhos infra-conscientes, mas da rêverie criadora de símbolos poéticos através da qual - a ciência só por si não chega lá - se entrará em relação mais íntima com o universo. O ilustre físico não é só filósofo pela simples razão de se ter tornado epistemólogo, longamente reflectindo sobre a ciência; ultrapassando Sérgio, neste aspecto, Bachelard voluntariamente sai dos círculos fechados de uma razão totalizadora, porque essa razão não explica tudo: e segue o caminho que se abrirá para um humanismo com outra amplitude, para uma cosmologia de reconciliação com o mundo, na certeza de que, tratando-se embora de domínios diferentes, nenhum deve ser desvalorizado.

O mito de Apoio e o mito de Dionísio: embora contraditórios (ou por isso mesmo), da não-separação radical de ambos resulta a harmonia, os Gregos sabiam-no apesar de, entre eles, a Razão ter despertado e, aparentemente, vencido. E não só Heraclito, o cantor da luta dos opostos, também Sócrates e o próprio Platão não abandonam facilmente o mito.

O Timeu fala-nos desse demiurgo que com três materiais diferentes - o mesmo, o outro e a mistura do mesmo e do outro - faz o mundo. A ciência move-se no domínio do mesmo, do uno, do invariante, do estável: o outro será um domínio que está fora do pensável - caos, desordem - que está fora da ciência, mas que Platão não rejeita abertamente. Platão fará, segundo Serres, «do pensável e do impensável uma terceira substância difícil de pensar.... é dada uma grande prioridade à mistura, quer dizer ao terceiro termo» $\left({ }^{46}\right)$.

$\mathrm{O}$ humanismo - a única forma de humanismo que interessará considerar - alimentar-se-á dessa mistura, onde há rigor e exactidão, unidade e multiplicidade, ordem e desordem.

Mas a desvalorização de um destes dois domínios é bem acentuada por Sérgio: na análise que faz aos «Dois Anteros», está bem explícito o salto "da inteligência do intelectual para a sensibilidade de um grande enfermo» $\left({ }^{47}\right)$; e não se trata só de Sérgio considerar que são «duas personagens incompatíveis», mas de, em relação à segunda, falar em «temperamento mórbido», acrescentando que «tem o primeiro por ideal hu-

$\left({ }^{45}\right)$ Gaston Bachelard, La poétique de la rêverie, Paris, P. U. F., 1974, p. 2 .

$\left({ }^{46}\right)$ Michel Serres, Genèse, Paris, Bernard Grasset, 1982, p. 183.

$\left({ }^{47}\right)$ Ensaios, IV, pp. 129-159. 
mano a plena emancipação do espírito adulto; o segundo, muito ao invés, o regresso à irresponsabilidade da criancinha, com o refúgio no colo de uma boa mãe».

Mas do que é tão claramente pensado, ao que é realmente vivido, vai uma grande distância: em carta particular, escrita a um amigo dilecto, em época muito distante dos últimos anos de depressão, Sérgio diria: «.....a impressão constante de dúvida, de que o que penso e digo é, ou pode ser sempre, absurdo ou erro evidente. Com a dúvida vem o mêdo: mêdo de cousa nenhuma em particular, mas um mêdo abstracto, mêdo daquilo que interiormente me pode suceder, um sentimento indefinido de ansiedade... de repente vem-me a impressão de que está tudo errado, sem que eu veja onde, nem como, nem porquê...»

Contradições de um racionalista?

Sérgio lamenta que Antero pense a morte em termos de «prece mórbida emocional» e não «reconheça intelectualmente a necessidade da morte»; e até numa questão tão paradoxal, como a morte, essa «ordem extraordinária». (Jankélévich), Sérgio reivindica claridades e rigores racionais. E espera que o filósofo cumpra a sua missão e que os traços intelectuais, apolíneos, centrípetos, prevaleçam ou dominem os românticos, nocturnos, centrífugos - doentes. Afinal em Antero, como diz, as perturbações causadas pela segunda tendência, irão influir (negativamente) na moral e na metafísica de «Primeiro Antero».

O que se opõe à razão ordenada é «lava negra no pensamento apolíneo».

E assim Sérgio se afasta de Platão - ou de Platão só faz leitura unilateral que não parece ser a melhor leitura — caindo no inferno dualista.

Não teria António Sérgio sofrido mais do que uma vez, em diversas épocas, e, continuadamente nos últimos dez anos da sua vida, os fogos deste inferno? 